Niepełnosprawność. Dyskursy pedagogiki specjalnej

Nr 30/2018

Disability. Discourses of special education

No. 30/2018

Ewa Jaglarz

Akademia Ignatianum w Krakowie

\title{
Jakościowa charakterystyka stylu zarządzania miejscem pracy ze względu na warunki sprzyjające zatrudnianiu osób z niepełnosprawnością
}

W artykule podjęto problematykę zarządzania zasobami ludzkimi w przedsiębiorstwach otwartego rynku pracy w zakresie warunków stwarzanych przez pracodawców sprzyjających zatrudnianiu osób z niepełnosprawnością. Zgodnie z przyjętą metodologią, skupiono się na wybranych aspektach organizacji pracy, w tym wypadku na wymaganiach stawianych pracownikom, stworzonej kulturze pracy oraz doświadczeniu w zatrudnianiu i wynikające z tego systemy wsparcia. W wyniku zastosowanej metody pokazano zróżnicowany jakościowo obraz badanych pracodawców otwartego rynku pracy w zakresie ich cech i stworzonych warunków zatrudnienia. Dokonana jakościowa analiza środowiska pracowniczego pod kątem wybranych aspektów może służyć działaniom doradczym dla osób zawodowo zajmujących się osobami z niepełnosprawnością, samym osobom z niepełnosprawnością, doradcom zawodowym, menedżerom oraz pracownikom socjalnym w poszukiwaniu środowiska jakościowo odpowiadającemu potrzebom osób $\mathrm{z}$ niepełnosprawnością na wolnym rynku pracy.

Słowa kluczowe: osoby z niepełnosprawnością, otwarty rynek pracy, zatrudnienie, pracodawca

\section{The qualitative analysis of the style of workplace management in regard to the conditions facilitating the employment of people with disabilities}

The article aims at the issue of human resources management at workplaces in the open labour market in regard to the conditions created by employers who are open to recruit people with disabilities. It focuses on some aspects of work organization such as: requirements for employees, the work culture as well as the recruitment experience and support schemes that follow. The qualitative methodology, that has been used, resulted in showing a diverse picture of the subject employers in regard to their characteristics and the hiring conditions they apply. A qualitative analysis of the workforce environment in terms of selected aspects facilitating the recruitment of people with disabilities may serve as an advisory tool for professionals dealing with the disabled, the disabled themselves, career development specialists, managers and social workers in searching for conditions that apply to the needs of people with disabilities in the open labour market.

Keywords: people with a disability, open labour market, employment, employer 


\section{Wprowadzenie}

Sposób w jaki zarządzane jest przedsiębiorstwo, może mieć istotny wpływ na otaczające środowisko społeczne. Biznes poprzez swoją działalność wpływa na społeczeństwo promując wartości, wytycza trendy w zarządzaniu kapitałem społecznym lub kładzie nacisk na szczególną racjonalizację zatrudnienia na podstawie planowanego zysku. Świadomość wywieranego wpływu na otaczające środowisko stanowi społeczną odpowiedzialność korporacji, rzutuje również na politykę zatrudnienia w drobnej, a nawet rodzinnej przedsiębiorczości ${ }^{1}$. Rozpowszechnianie świadomości społecznej odpowiedzialności przedsiębiorców może przyczynić się do skutecznego zatrudniania osób z niepełnosprawnością, powodować swoiste „oswajanie” odmienności i promować egalitarny system włączający osoby z niepełnosprawnością w główny nurt otwartego rynku pracy. W naszym kraju problem niskiego wskaźnika zatrudnienia osób z niepełnosprawnością obserwuje się od lat. Obecnie łącznie na 3,4 mln osób z niepełnosprawnością, z czego ponad 2,1 mln jest $\mathrm{w}$ wieku produkcyjnym, pracuje tylko nieco ponad 27\% [PBON 2012]. Tylko 7\% osób z niepełnosprawnością utrzymuje się wyłącznie z własnej pracy [Czapliński 2010: 3].

Społeczeństwo generalnie deklaruje aprobatę dla modelu integracyjnego, włączającego osoby z niepełnosprawnością do normalnie funkcjonujących grup i instytucji społecznych na równi z ludźmi "sprawnymi” [Ostrowska, Sikorska 1996; Ostrowska 1997, 2002; Ochonczenko 2002]. Prym w tym wiodą studenci kierunków nauczycielskich, przyszłych nauczycieli oddziałów integracyjnych w szkołach. Blisko 96\% wyraża pozytywny stosunek do integracji szkolnej. Jednak jednocześnie większość (90\%) nie widzi siebie jako pracownika w zespole integracyjnym [Domagała-Kręcioch, Zawisza 2002: 305]. Również liderzy środowisk lokalnych, którzy znają akty prawne dotyczące osób niepełnosprawnych, często (60\%) wybierają integracyjny model funkcjonowania osób z niepełnosprawnością w społeczeństwie. Podobnie znaczny odsetek osób (72\%) uważa, że osoby $\mathrm{z}$ niepełną sprawnością powinny być włączane $\mathrm{w}$ środowisko pracownicze również na otwartym rynku pracy [Ochonczenko 2002: 317].

Identyfikacji istniejących barier w zatrudnianiu osób z niepełnosprawnością dokonał Garbat, analizując wyniki empirycznych badań środowiska pracowniczego. Wśród czynników będących po stronie pracodawców ustalił determinanty:

\footnotetext{
1 Raport z badań społecznej odpowiedzialności biznesu ujawnił, że wiedza dotycząca CRS (Corporate Social Responsibility) w Polsce jest niewystarczająca. Około $40 \%$ badanych organizacji angażuje się we wdrażanie zasad biznesu odpowiedzialnego społecznie, $33 \%$ nie wie czy zajmie się tą problematyką w przyszłości, a $25 \%$ w najbliższym czasie na pewno nie zamierza wdrożyć zasad CRS. Raport $z$ badań CRS w Polsce. Menedżerowie/Menedżerki 500, Lider/Liderka CRS, GoodBrand\&Company Polska, Warszawa 2010, s. 7-9.
} 
a) związane z osobami niepełnosprawnymi - brak odpowiednich kwalifikacji i możliwości fizycznych, krótki lub brak stażu pracy i doświadczenia zawodowego, wygląd zewnętrzny, złe nastawienie do pracy, niska wydajność pracy, niska jakość pracy;

b) związane z pracodawcami - lęk przed możliwością integracji niepełnoprawnego pracownika w miejscu pracy z kadrą kierowniczą, obawa przed koniecznością specjalnych przystosowań, zła polityka kadrowa zakładów pracy w zakresie awansowania, wynagradzania, szkolenia i rozwoju zawodowego, zbyt mała pomoc zakładów pracy w zakresie rehabilitacji medycznej, nieznajomość przepisów ustawy o rehabilitacji;

c) związane z sytuacją na otwartym rynku pracy - ogólne bezrobocie, ale w ograniczonym zakresie [Garbat 2007: 205-207].

Z kolei Woźniak uznał, iż postawy pracodawców wobec zatrudniania osób z ograniczeniem sprawności są pochodną syndromu czterech lęków:

a) obawą przed kosztami związanymi z zatrudnieniem,

b) lękiem przed pozaekonomicznym nadzorem zewnętrznym związanym $z$ kontrolami,

c) lękiem przed zablokowaniem etatu bowiem niepełnosprawni są szczególnie chronieni nawet jeśli nie wywiązują się z obowiązków pracowniczych,

d) lękiem przed stratami ekonomicznymi, nie chcą ryzykować marki i wszystkiego co się wiąże z profitami [Woźniak 2007: 69-84].

Jak podają dane statystyczne, większość pracodawców niechętnie zatrudnia osoby z niepełnosprawnością. Ponad jedna trzecia pracodawców nie zatrudnia osób poruszających się na wózku, a prawie połowa średniej wielkości przedsiębiorstw w ogóle nie zatrudnia osób z niepełnosprawnością. Wśród większych przedsiębiorstw odsetek ten jest znacznie niższy, ale tylko co czwarte zatrudnia wymaganą przepisami liczbę osób z niepełnosprawnością [ISP ZUS 2009].

Badania opinii pracowników o pracodawcach $\mathrm{w}$ aspekcie społecznej odpowiedzialności biznesu z zakresu zatrudniania osób z niepełnosprawnością ujawniły wiele stereotypowych poglądów:

a) zdecydowana większość rozmówców utożsamia pracownika niepełnosprawnego z osobą na wózku. Wiązało by się to z koniecznością dostosowania miejsc pracy i budynku do potrzeb poruszających się niesamodzielnie;

b) wielu respondentów zwracało uwagę na konieczność pełnej sprawności ruchowej do właściwego wykonywania obowiązków;

c) jeśli chodzi o charakter pracy, to respondenci często wskazywali na pracę biurową jako właściwą dla osób z niepełnosprawnością;

d) pojawiły się wypowiedzi przytaczające pozytywny przykład organizacji, która dostosowała miejsca pracy i stanowisko pracy, lecz kontynuację pracy uzależniano od posiadanych kompetencji zatrudnionego; 
d) tematem powtarzającym się $\mathrm{w}$ wypowiedziach był powrót do pracy po wypadku. Niestety w wielu przypadkach zakończył się on niepowodzeniem i pracownicy nie mogli kontynuować zatrudnienia [Miedzianowska 2013: 344-347].

\section{Metodologia badań własnych}

Celem badań była analiza społecznej świadomości podmiotów biznesu w zakresie stwarzanych warunków, które przez swoją specyfikę mogłyby sprzyjać bądź utrudniać zatrudnianie osób z niepełnosprawnością. Przeprowadzone badania opinii i doświadczeń pracodawców służyły charakterystyce środowiska pracowniczego otwartego rynku pracy $\mathrm{w}$ zakresie takiego organizowania środowiska pracy, które poprzez swoje cechy stałyby się sprzyjające dla osób z niepełnosprawnością. W szczególności badania dotyczyły aspektów społecznej odpowiedzialności biznesu w wymiarze wewnętrznym, a więc nakierowanym na pracownika - kultury pracy, wymagań zawodowych stawianych pracownikom oraz doświadczenia, jakie wykazują pracodawcy w zatrudnianiu i zarządzaniu kapitałem ludzkim [Bartkowiak, Krugiełka 2012].

Dennis Gilbride, Robert Stensrud, Kristie Golden i David Vandergoot [2003] na podstawie badań własnych, dzięki jakościowej metodzie teorii ugruntowanej, opracowali model pracodawcy otwartego na zatrudnianie osób z niepełnosprawnością, który odpowiada podstawowym założeniom świadomego uczestnictwa $\mathrm{w}$ społecznych skutkach organizacji przedsiębiorstwa. W modelu tym skupiono się na realizowaniu go poprzez właściwe zarządzanie zasobami ludzkimi, czyli taką organizację biznesu, która uwzględnia egalitaryzm, integrację i wsparcie. Według autorów pracodawca otwarty na zatrudnienie osób z niepełnosprawnością będzie prezentował postawy i przekonania w obszarach uznanych za kluczowe $w$ organizacji: kulturze pracy wyrażonej w normach i wartościach, stawianych wymaganiach zawodowych ze strategia polityki personalnej oraz $\mathrm{w}$ zagadnieniach związanych z doświadczeniem i wsparciem z całym systemem motywacji i nagród. Pomijany jest aspekt korzyści materialnych, jakie łączą się z zatrudnianiem osób z niepełnosprawnością oraz dążenie do jakości i efektywności finansowej przedsiębiorstw. Autorzy skupili się na stylu zarządzania, który przez swoje cechy sprzyjałby zatrudnianiu osób z niepełnosprawnością [Gilbride i in. 2003].

Autorzy w wyniku przeprowadzonych badań - jakościowej analizy wywiadów swobodnych pracodawców - dokonali kodyfikacji cech i stylów zarządzania zatrudnieniem. Powstała ankieta zwana kwestionariuszem EOS (Employer Opennes Survey $)^{2}$, zawierająca następujące kategorie: kultura pracy, wymagania zawo-

2 Ankieta Otwartości Pracodawcy (Employer Opennes Survey) zwana EOS została przekazana w celu przeprowadzenia badań bezpośrednio od autora Dennise'a Gilbride'a na prośbę zainteresowanej autorki niniejszego artykułu z wyrażeniem zgody na wykorzystanie w badaniach własnych. 
dowe, doświadczenie i wsparcie pracodawcy. Wszystkie te kategorie zostały skonkretyzowane w postaci utworzonych 13 pytań otwartych stanowiących scenariusz wywiadu [Gilbride i in. 2003].

W badaniach własnych posłużono się wypracowanym przez Gilbride'a scenariuszem wywiadu EOS przeznaczonym dla pracodawców otwartego rynku pracy. Na jego podstawie dokonano analizy jakościowej cech pracodawcy. Wywiad miał charakter niestrukturalizowany - pozwalał na swobodne wypowiedzi rozmówców [Kostera 2003: 122]. Na końcu kwestionariusza zawarto dodatkowe pytania metryczkowe, charakteryzujące pracodawcę. $\mathrm{W}$ tabeli 1 zawarto wszystkie pytania scenariusza wywiadu według kategorii ustalonych przez Gilbrida wraz ze współpracownikami.

Tabela 1. Kategorie i pytania opisujące cechy pracodawcy i środowiska pracowniczego (wg numeracji w kwestionariuszu)

\begin{tabular}{|c|c|c|}
\hline Kultura pracy & Wymagania zawodowe & $\begin{array}{c}\text { Doświadczenie } \\
\text { i wsparcie pracodawcy }\end{array}$ \\
\hline $\begin{array}{l}\text { 1. Jakie są mocne punkty Pana } \\
\text { Firmy? }\end{array}$ & $\begin{array}{l}\text { 3. Z jakich form rekrutacji ko- } \\
\text { rzystacie Państwo w celu znale- } \\
\text { zienia odpowiednich kandyda- } \\
\text { tów? }\end{array}$ & $\begin{array}{l}\text { 11. Czy Pana przedsiębiorstwo } \\
\text { posiada system motywacji dla } \\
\text { indywidualnych pracowników, } \\
\text { zespołów, sektorów? Podać } \\
\text { przykłady. }\end{array}$ \\
\hline $\begin{array}{l}\text { 2. Jakie są główne problemy dy- } \\
\text { rektora naczelnego pańskiego } \\
\text { przedsiębiorstwa? }\end{array}$ & $\begin{array}{l}\text { 4. W jaki sposób nowoczesna } \\
\text { technologia zmieniły Państwa } \\
\text { możliwości kontaktu z kandy- } \\
\text { datami poszukującymi pracy? }\end{array}$ & $\begin{array}{l}\text { 14. Jakiego typu programy inte- } \\
\text { gracyjne zapewnia Pana przed- } \\
\text { siębiorstwo i kto w nim bierze } \\
\text { udział? }\end{array}$ \\
\hline $\begin{array}{l}\text { 12. W jaki sposób komunikuje } \\
\text { się Pan oraz uzyskuje informa- } \\
\text { cję zwrotną od swoich pracow- } \\
\text { ników? }\end{array}$ & $\begin{array}{l}\text { 6. Jakie cechy osobowe oraz wy- } \\
\text { magania powinny spełniać oso- } \\
\text { by które zamierzacie Państwo } \\
\text { zatrudniać? }\end{array}$ & $\begin{array}{l}\text { 15. Jeżeli nowy lub dotychczaso- } \\
\text { wy pracownik prosi o przeszko- } \\
\text { lenie, do kogo kieruje go Pan } \\
\text { w celu udzielenia pomocy? }\end{array}$ \\
\hline $\begin{array}{l}\text { 18. Z czego jest Pan najbardziej } \\
\text { dumny w Pana firmie? }\end{array}$ & $\begin{array}{l}\text { 7. Jakie kryteria lub sposoby oce- } \\
\text { ny wykorzystujecie Państwo } \\
\text { w celu określenia przydatności } \\
\text { kandydata na stanowisko? }\end{array}$ & $\begin{array}{l}\text { 16. Jak sobie Pan radzi z sytu- } \\
\text { acjami gdy pracownik wraca do } \\
\text { pracy po dłuższej chorobie lub } \\
\text { wypadku? }\end{array}$ \\
\hline \multirow[t]{2}{*}{$\begin{array}{l}\text { 10. Czy kierownicy mają możli- } \\
\text { wość elastycznego wyznaczania } \\
\text { zadań w oparciu o silne i słabe } \\
\text { strony pracownika? }\end{array}$} & $\begin{array}{l}\text { 8. Gdyby miał Pan wybrać, wy- } \\
\text { brałby Pan kogoś kto szybko się } \\
\text { uczy, lub kogoś kto jest pod- } \\
\text { porządkowujący się? Dlaczego? }\end{array}$ & $\begin{array}{l}\text { 17. Jaka była szczególnie efek- } \\
\text { tywna akcja podjęta w Pana } \\
\text { przedsiębiorstwie w celu pro- } \\
\text { mocji idei integracji w miejscu } \\
\text { pracy? }\end{array}$ \\
\hline & $\begin{array}{l}\text { 9. Czy prowadzicie system sta- } \\
\text { żów i przyuczania do zawodu } \\
\text { i jakie są to formy? }\end{array}$ & \\
\hline
\end{tabular}

Źródło: [Gilbride i in. 2003: 130-138]. 


\section{Wyniki badań własnych}

W badaniach własnych uczestniczyło 58 pracodawców otwartego rynku pracy z terenu województwa małopolskiego. W gronie tym w większości znaleźli się pracodawcy mający siedzibę zakładu w dużym mieście liczącym ponad 100 tys. mieszkańców (64\%). Spośród pracodawców działających na wsi w badaniu udział wzięło 7 respondentów. Tylko czterech pracodawców reprezentowało małe miasto, a siedmiu miasteczko powyżej 25 tys. Ze względu na rodzaj działalności najmniej liczną grupą była grupa pracodawców z sektora publicznego (7 ankietowanych, tj. 12\% wszystkich respondentów). Najliczniejszą reprezentację stanowili pracodawcy sektora przemysłowego (28 respondentów, czyli 48\% ogółu badanych). Usługi reprezentowało 19 pracodawców, co stanowiło 33\% wszystkich analizowanych respondentów.

Ze względu na wielkość przedsiębiorstwa zatrudniające do dwudziestu pięciu pracowników stanowiły $28,5 \%$ ogółu respondentów, liczba biorących udział w badaniu średnich przedsiębiorstw z zatrudnieniem w zakresie 20-100 pracowników wynosiła 17, co stanowiło 30,3\% ogółu, a duże przedsiębiorstwa powyżej 100 pracowników reprezentowane były w $41 \%$.

Ponad połowę respondentów stanowili pracodawcy, którzy nie zatrudniali osób z niepełnosprawnością (53\%). Ci którzy zatrudniali, lecz nie przekroczyli ustawowo wymaganego progu $6 \%$ zatrudnienia osób z niepełnosprawnością, stanowili $22 \%$ wszystkich ankietowanych. Zakłady pracy spełniające wymóg procentowego udziału osób z niepełnosprawnością w całości zatrudnionej załogi stanowili również $22 \%$ badanej populacji, przekłada się to na reprezentację 13 zakładów pracy. Wśród badanych pracodawców nie znalazły się zakłady pracy chronionej ani zakłady aktywizacji zawodowej.

W przeprowadzonych badaniach własnych udzielone odpowiedzi na postawione pytania dały obraz pracodawcy ze względu na jego skłonność do zatrudniania i odpowiedź na czym polega styl, który prezentują poszczególne kategorie. Uwzględniając wyodrębnione obszary w otrzymanych odpowiedziach uzyskano jakościową charakterystykę pracodawcy na otwartym rynku pracy ze względu na skłonność do zatrudniania osób z niepełnosprawnością.

\section{Kultura pracy}

Przy rozważaniu odpowiedzialności społecznej szczególne znaczenie mają podstawowe wartości danej kultury pracy. Dla autorów kategorii opisujących pracodawcę prezentowane przez nich wartości są przedmiotem względnie 
trwałych celów i mogą dotyczyć pracowników, klientów bądź produkcji. Dla wyodrębnionych przez Gilbride'a ze wspólpracownikami typów pracodawcy różne obiekty są wartościami, które realizują w trakcie działalności gospodarczej [Gilbride i in. 2003].

Według autorów ankiety EOS dla przedsiębiorcy skłonnego do zatrudniania osób z niepełnosprawnością szczególnym przedmiotem zainteresowania powinien być pracownik. Pracodawca docenia wówczas mocne strony pracownika, doskonali i wspiera jego umiejętności, dopasowuje wymagania i miejsce pracy zgodnie z posiadanymi atutami. Pracodawca stosuje zasady równości i dba o właściwą atmosferę w pracy.

W uzyskanych odpowiedziach pojawily się wśród pracodawców twierdzenia doceniające formalne kompetencje pracownika: „najmocniejszym punktem są dobrze wyszkoleni pracownicy na każdym etapie produkcji", gdzie indziej w wypowiedziach pojawia się "wykwalifikowana kadra pracownicza” oraz docenione zostają "kwalifikacje pracowników”, „profesjonalizm, kompetencje, elastyczność". Dla pracodawcy ważny jest pracownik taki, który posiada cechy przydatne w organizacji. Miejsce pracy powinni więc zajmować pracownicy kompetentni. Pracodawca identyfikowany jako otwarty dostrzega możliwości osoby zatrudnionej, a nie inne jej cechy, mniej istotne ze względu na zajmowane stanowisko. Niektórzy dostrzegają korzyści z różnorodności jaką wnoszą pracownicy: „wysokie kwalifikacje pracowników, mieszanka doświadczenia i młodości" oraz to co wiąże się z osobistym stosunkiem do powierzonych zadań. Doceniani są: "pracownicy wykonujący swoje obowiązki z dużym zaangażowaniem” oraz "personel dążący do rozwoju przedsiębiorstwa i rozwoju osobistego". Dobry pracodawca widzi potrzebę rozwoju pracownika i dba o jego dokształcanie stąd wielokrotnie w wypowiedziach pojawia się „podnoszenie kwalifikacji pracowników”. U jednego dokształcanie przybrało charakter systemu:

„przejawia się szkoleniami, z których mogą korzystać pracownicy”, gdzie „(..) system dokształcania pracowników pozwala nie tylko zdobywać pracownikom doświadczenie, ale również rozwija ich osobowościowo".

W niektórych wypowiedziach pojawił się egalitaryzm skierowany szczególnie na osoby z niepełnosprawnością. Respondenci zaakcentowali:

„równe traktowanie osób niepełnosprawnych i pełnosprawnych" (połączone z) „możliwością zatrudnienia osób niepełnosprawnych" (dzięki) „indywidualnemu podejściu do pracownika” (i) „dużej znajomości problematyki osób niepełnosprawnych”.

Spośród cech, jakimi charakteryzowały się zakłady pracy, najbardziej cenione były: „stałość zatrudnienia” i „stabilność przedsiębiorstwa, stabilność w kadrze kierowniczej” oraz „innowacyjność jaką wykazywał się zespół pracowników”. 
Z udzielonych odpowiedzi wynika, że cenioną wartością pracodawcy są kompetencje i fachowość pracownika, które systematycznie podnoszone, sprzyjają rozwojowi firmy. Firma postrzegana jest jako stałe miejsce pracy, w którym można się rozwijać i wprowadzać własne pomysły.

Pracodawcy zorientowani na pracownika zwracają większą uwagę na motywowanie pracowników niż na ich kontrolowanie. Dążą do przyjaznych, pełnych szacunku i opartych na wzajemnym zaufaniu stosunków z pracownikami. Stąd cenią sobie swoją kadrę pracowniczą, atmosferę życzliwości i współpracy:

„najwięcej satysfakcji sprawia mi przyjście byłego już pracownika w celu odwiedzin czy wsparcia, albo pochwalenia się swoimi osiągnięciami (nawet osoby które zwolniłem prawie dyscyplinarnie), wydaje mi się, że o to chodzi głównie w mojej firmie, aby atmosfera jaką tworzę, pozwalała godnie wypełniać obowiązki pracownicze".

Wybieganie poza partykularne interesy firmy powoduje osiąganie także pozabiznesowych celów, które są pożądane społecznie, jak choćby pomyślnie przebiegający, dzięki zatrudnieniu, proces socjalizacji osób z niepełnosprawnością. Zdobywają wówczas miękkie i twarde kompetencje dzięki temu, że uzyskali zatrudnienie i funkcjonują w szerszej grupie społecznej. Pracodawcy cenią osoby z niepełnosprawnością, "którzy uczą się umiejętności pracy i współpracy w zakładzie". Doceniają tym sposobem społeczne korzyści jakie wiążą się z obcowaniem w miejscu pracy osób z niepełnosprawnością z osobami pełnosprawnymi.

Pracodawca identyfikowany przez Gilbride’a ze współpracownikami [2003] jako neutralny, to przede wszystkim producent dbający o kontakty z klientami i jakość wykonywanych usług. Zwraca uwagę na człowieka jak na potencjalnego odbiorcę efektów pracy organizacji. Im lepiej postrzegana jest organizacja przez pryzmat zadowolenia klientów, tym lepiej dla pracowników i zarządu. Pracownik jest tym bardziej ceniony, im lepiej spełni oczekiwania klienta. Zadowolenie z otrzymanych usług lub towaru, zdolnośći elastyczność we wspólpracy z kontrahentami jest miernikiem dobrze wykonanej pracy i kompetencji pracowników. Stąd $\mathrm{w}$ badaniach własnych i w wypowiedziach pracodawców pojawia się jako szczególny przedmiot dumy - wykwalifikowany personel, który wykazuje „elastyczne i szybkie dostosowanie się do zmieniającego rynku i zindywidualizowane traktowanie klienta”, określane również jako „elastyczność w podejściu do klienta". Niektórzy respondenci doceniali:

„otwartość na nowe kontakty z kontrahentami oraz sposoby zbytu towarów, dostrzeganie nowych trendów na rynku".

Nieliczni chwalą sobie zdolność do funkcjonowania na międzynarodowych rynkach. Dwaj pracodawcy wypracowali status międzynarodowego współpracownika i deklarują: 
"stałą współpracę z dużymi polskimi i międzynarodowymi koncernami" oraz „współpracę z dużymi kontrahentami z Polski i zagranicy”.

Wszystko to skutkuje „zaufaniem ze strony klientów”, wobec których dodatkowo usługodawcy wyrażają „chęć pomocy (...), nie zostawiamy go (klienta) własnym problemom". W znacznej mierze pracodawca neutralny skupia się na potrzebach klienta, jego zadowoleniu z otrzymanego produktu. Zwraca większą uwagę na wykonanie pracy niż na rozwój czy osobiste zadowolenie pracowników. W stylu tym pracodawca bardziej zorientowany jest na zadaniu, a nadzór nad pracownikiem ograniczać się może do właściwie wykonanego zadania. Styl ten najczęściej spotykany jest w organizacjach usługowych, gdzie warunkiem sukcesu jest zaspokojenie priorytetów potencjalnych klientów.

Dla neutralnego stylu sprawowanego przywództwa najbardziej charakterystyczny będzie pracodawca, który docenia przede wszystkim dobrą jakość swojego produktu [Gilbride i in. 2003]. Respondenci dumni są z „wypromowania marki” i „z rozpoznawalności marki w środowisku”. Najpełniej charakteryzuje to respondent, którego rozpiera duma z osiągnięć:

„status i marka, którą firma osiągnęła na rynku, firma, czyli właściciele wraz z pracownikami, ale właściciel jest mózgiem i realizuje swoje idee razem z całym zespołem".

Właściwie zadowolony klient to najwyższy cel jaki stawiają sobie pracodawcy charakteryzowani jako neutralni. Dobry produkt, wysoka jakość to środek do pożądanego celu, stąd wypowiedzi ankietowanych o „dobrej jakości swoich wyrobów”, "wydajności”, "rzetelności w pracy” i dumy z

„wyników produkcyjno-ekonomicznych, wspaniałej fachowej załogi, spełniania norm jakości przez posiadanie certyfikatów ISO".

Dla pracodawcy neutralnego w konsekwencji ważna jest uzyskana kondycja finansowa firmy i pozycja na rynku - dumni są np. $\mathrm{z}$ „rozwoju firmy oraz tytułu "Gazela Biznesu" oraz

„z dynamicznego rozwoju firmy, pozycji lidera na rynku polskim i ekspansji na zachodnie rynki".

Najbardziej zamkniętym na zatrudnianie osób niepełnosprawnych typem pracodawcy jest biznesmen zorientowany na wynikach produkcji uzależnionej od użytych technologii, parku maszynowego, wyposażenia miejsca pracy. Ceni sobie osiągniętą pozycję na rynku pracy w oparciu o sprawne zarządzanie [Gilbride i in. 2003]. Typowej wypowiedzi udzielił przedstawiciel jednego z największych badanych zakładów pracy branży energetycznej, który zwrócił uwage szczególnie na „niezawodność w produkcji i dostawie energii elektrycznej i cieplnej, dobre wyniki finansowe firmy, wprowadzenie i doskonalenie zintegrowanego systemu zarządzania, ciągły rozwój firmy poprzez nowe inwestycje". 
Osiąganie doskonałych wyników produkcyjno-ekonomicznych połączonych z dążeniem do nowoczesności parku maszynowego i uzależnianie wyników od jakości tego parku daje obraz odhumanizowanego miejsca pracy, w którym niewiele zależy od pracownika. Dlatego wartością, do której szczególnie dąży zidentyfikowany jako zamknięty typ pracodawcy, to stały rozwój:

„wprowadzanie nowych rozwiązań i technologii, komputeryzacji, dodatni wynik finansowy zakładu pracy".

Ceni też sobie stałość osiąganych efektów określaną jako „stabilność finansową przedsiębiorstwa” bądź "stabilną rentowność". W tak zarządzanej firmie nie ma miejsca dla osób z niepełnosprawnością. Zbyt duża obawa pracodawcy o wyniki finansowe firmy nie pozwoli na zatrudnienie niepełnosprawnego obarczonego ryzykiem mniejszej wydajności. Takich pracodawców w badanej populacji jest niewielu. Należą do nich wielkie korporacje, które są monopolistami na rynku.

W sposobie komunikowania się z pracownikami większość respondentów preferuje bezpośredni kontakt z podwładnym. Niezależnie od preferowanego stylu zarządzania rozmowa z pracownikiem uznana jest za najwłaściwszy sposób komunikowania się. Rozmowa jest wykorzystywana jako narzędzie kontroli oraz zgłaszania problemów wyższemu szczeblowi. Rozmowy w zależności od potrzeb przybierają charakter bardziej lub mniej formalny. W celu wypracowania strategii firmy, uzgodnień dotyczących produkcji, przekazania wskazówek do pracy pracodawcy organizują stałe cykliczne formy kontaktu z pracownikami przybierające postać „polityki otwartych drzwi, cotygodniowych spotkań operacyjnych z pracownikami”, "narad produkcyjnych", "narad produkcyjno-organizacyjnych z kierownikami robót" lub organizowane są "przynajmniej raz w miesiącu spotkania całej firmy, wszystkich pracowników". Komunikacja w dół zazwyczaj jest zatrzymywana na poszczególnych stopniach i odbywa się z zachowaniem hierarchii zarządzania poprzez „zebrania grup członkowskich, rozmowy z przedstawicielami zarządów organizacji związkowych, rady nadzorczej, walne zgromadzenie". Aby usprawnić komunikację w dół pracodawcy skracają drogę formalizując przekaz do "tablic informacyjnych", „,notatek służbowych”, ,raportowaniu”, ,obiegu pism urzędowych", „nakazu”, wykorzystują też najnowsze techniki komputerowe w postaci maili i skypa. Podwładni, aby przekazać swoje uwagi i wnioski, a więc komunikując się w górę, mają możliwość skontaktowania się z wyższym szczeblem kierowniczym dzięki bezpośrednim i częstym kontaktom „poprzez kierowników komórek organizacyjnych”, „poprzez bezpośrednią rozmowę lub za pośrednictwem przełożonego" lub po prostu pracodawca deklaruje:

„często rozmawiam z pracownikami, wiedzą, że mogą zwrócić się do mnie z każdym problemem". 
Bywają pracodawcy, którzy mówią o sobie, iż „przywiązujemy dużą wagę do kontaktów osobistych" i są blisko pracownika gdyż:

„pracownicy mogą zgłaszać swoje uwagi przełożonemu, ten jest obowiązany przekazać je dyrekcji. Raz w tygodniu każdy pracownik może osobiście przekazać swoje uwagi dyrektorowi".

Komunikacja $\mathrm{w}$ górę ulega filtrowaniu, zatrzymaniu na poszczególnych szczeblach, i aby usprawnić jej przebieg, pracodawca uruchomil „zapytania przez Internet".

Pracodawcy, którzy wykazują otwarcie na zatrudnianie osób niepełnosprawnych, będą korzystali z różnych kanałów komunikacyjnych. Zaledwie kilku respondentów wykazało więcej niż trzy takie kanały o zróżnicowanym sposobie przekazu (linia telefoniczna, Internet, bezpośredni kontakt). Pojawiły się nowe techniki komunikacyjne, które zwiększyły dokładność i szybkość komunikacji $\mathrm{w}$ organizacjach oraz stały się wyzwaniem dla tradycyjnego sposobu sprawowania władzy. Pracodawcy zaspokajają potrzeby komunikacyjne jedynie dzięki rozmowom i bezpośrednim kontaktom, przy czym relacje te nie wykazują cech formalnego lub systematycznego podejścia. Utrudnia to kontakt z pracownikami i sprawia, że pracodawca staje się niedostępny dla zatrudnionej osoby.

W wyniku konsultacji i rozmów istnieje perspektywa stworzenia takiej organizacji pracy, aby zakres obowiązków mógł być dopasowany do możliwości pracownika i modyfikowany na bazie jego słabych i mocnych stron. Respondenci wykazują elastyczność w podejściu do pracownika. Najpełniejsze uzasadnienie takiego elastycznego podejścia podają tacy pracodawcy, którzy dostrzegają cechy pracownika na stanowisku pracy i adekwatnie diagnozują jego przydatność do przydzielonych czynności. W wypowiedziach pracodawców znalazły się cechy, jakimi kierują się pracodawcy w celu dostosowania wymagań wobec pracownika. O rodzaju powierzonych zadań decydują:

- kompetencje miękkie:

„jak najbardziej, kierownicy wyznaczają zadania do realizacji na podstawie cech osobowościowych pracownika".

- kompetencje twarde:

„pracownicy zdolni, odpowiedzialni (...) są typowani przez kierowników na szkolenia specjalistyczne na bardziej odpowiedzialne stanowiska i tym samym lepiej płatne".

- doświadczenie:

„tak, zawsze jest to ustalane indywidualnie, a zwłaszcza wtedy kiedy osoba nie ma doświadczenia na stanowisku które obejmuje".

- rodzaj niepełnosprawności:

„głównie jest to uzależnione od niepełnosprawności pracownika, wieku, stażu, doświadczenia, wykształcenia". 
Inaczej motywują brak elastyczności w podejściu do pracownika ci pracodawcy, którzy nie widzą szans na dostosowanie powierzonych zadań. Wówczas pracodawcy uzasadniają swoje decyzje lapidarnym "nie”. Szersze podanie powodu takiej decyzji udało się tylko jednemu pracodawcy: „nie ma takiej możliwości cała grupa pracowników wykonuje takie same zadania". Ogólnie pracodawcy dali się poznać jako otwarci na zmiany i dostosowujący zadania do możliwości pracowników. Deklarują elastyczność w podejściu do wyznaczania obowiązków, licząc się z cechami jakie prezentuje kandydat na stanowisko.

Jeśli chodzi o identyfikowane przez firmy problemy, można zauważyć wyraźną polaryzację tych problemów na dwa bieguny. Jednym biegunem jest obszar problemów związany z pracownikami, drugim - zajmujący się produkcją i wynikami finansowymi firmy. Pierwszy typ pracodawcy - „przychylny” zatrudnianiu osób z niepełnosprawnością - będzie zwracał uwagę na dobrostan pracowników, ich prawa i powinności wobec firmy. Przedmiotem zmartwienia były „okresy zmniejszonych dochodów, które nie pozwalają nagradzać pracowników tak jakbym tego chciał”. Dla jednego pracodawcy stało się ważne, w jaki sposób „motywować pracowników" do lepszej pracy. Przedmiotem troski stał się niewydolny system zarządzania zasobami ludzkimi, jaki funkcjonuje $\mathrm{w}$ organizacji: „zarządzanie, brak jasnego i konkretnego systemu, brak jasnego systemu awansu i wynagrodzen" a dla innego pracodawcy „organizacja nadzoru nad pracownikami”.

W kwestii pracowników wielokrotnie powtarza się problem wysokiej rotacji spowodowanej wyjazdami do pracy za granicę, brakiem kompetentnej kadry pracowniczej oraz trudności $\mathrm{w}$ zarządzaniu pracownikami niższego szczebla: "trudności w egzekwowaniu wymagań od personelu niższego szczebla” i „brak chętnych do pracy na niższych stanowiskach".

Wśród pracodawców pojawiły się również specyficzne wypowiedzi traktujące o osobach z niepełnosprawnością. Dla jednego przedmiotem zmartwienia było „utrzymanie wysokiego wskaźnika zatrudnienia osób niepełnosprawnych”. Inny pracodawca traktował zatrudnianie osób z niepełnosprawnością jako konieczność wynikającą z przepisów prawa i niespełnianie tego obowiązku upatrywał jako źródło swoich problemów: „obowiązuje 6\% wskaźnik, którego instytucja jeszcze nie spełnia". Warto zauważyć, że deklarowane problemy wiążą się z realizacją jednego celu, jakim jest finansowa kondycja firmy. Niezatrudnianie bądź zatrudnianie osób z niepełnosprawnością poniżej sześcioprocentowego progu, tak jak mówi o tym ustawa, powoduje trudności finansowe firmy w związku z płaceniem składek na fundusz PFRON. Zaledwie jeden pracodawca podniósł kwestię faktycznych potrzeb pracujących osób z niepełnosprawnością. Wiążą się dla niego z celowym doborem miejsc pracy, a więc z zastosowaniem doradztwa zawodowego dla osób z niepełnosprawnością oraz z dystrybucją pomocy rzeczowej w postaci sprzętu rehabilitacyjnego. Zwerbalizował to jako trudność „Z dotarciem 
z programem pomocy w zaopatrzenie w sprzęt do osób niepełnosprawnych, dobór odpowiednich osób na stanowisko". Inny pracodawca, zapewne dużo bardziej doświadczony $\mathrm{w}$ zatrudnianiu osób z niepełnosprawnością, narzekał na konkurencję, której „nie sposób sprostać ze względu na mniejszą wydajność osób niepełnosprawnych".

Większość organizacji prezentuje postawę zorientowaną na produkcję, a dostrzegane przez nich problemy identyfikują jako źródło ograniczeń w osiąganiu jak najlepszych wyników finansowych. Pracodawca stawiający na pierwszym miejscu problemy związane z produkcją, technologiami, kosztami i dochodem, to w typologii Gilbride'a kolejny typ pracodawcy - zamkniętego na zatrudnianie osób z niepełnosprawnością [Gilbride i in. 2003). Otrzymane „zamknięte" odpowiedzi można pogrupować w dwie kategorie. Warto jednak zaznaczyć, że prezentowane problemy występowały często równocześnie, czyli funkcjonowanie na rynku było źródłem występowania więcej niż jednego typu trudności. Parafrazując więc zadane pytanie każdemu przedsiębiorcy, mają oni troski, bowiem:

a) źródłem dostrzeganych problemów przedsiębiorstwa są według pracodawców czynniki zewnętrzne. Uważają, iż mają trudności z realizacją swoich podstawowych zadań biznesowych ze względu na środowisko, w jakim przychodzi im funkcjonować. Poprzez środowisko rozumieją niedostosowane do potrzeb pracodawców ustawodawstwo i wynikające z tego rozporządzenia:

„stare prawo spółdzielcze stwarzające problemy w samodzielnym kierowaniu przedsiębiorstwem”, „polityka podatkowa państwa, co źle wpływa na wynagrodzenie pracowników",

oraz nagromadzenie wymaganych formalności $\mathrm{w}$ działalności organizacji: "zbyt dużo urzędowych spraw”. Przedsiębiorcy skarżą się na "nieciągłość finansową ze względu na przepisy" $i$ „nadmierną biurokrację $w$ systemie prawnym i administracyjnym". Dostrzegają też zbyt silną pozycję związków zawodowych: "duża liczba związków zawodowych o różnych roszczeniach”, które to najczęściej powodują zwiększenie ochrony socjalnej co wiąże się z dodatkowymi kosztami. Mimo że pracodawcy funkcjonują na otwartym rynku pracy, narzekają na „konkurencję, która przy braku stabilności przepisów" agresywnie wchodzi na rynek. Dochodzą według pracodawców trudności z przekształcaniem aktywów w gotówkę w celu pokrywania bieżących potrzeb z powodu "długich terminów płatności za wykonane usługi” i „nieterminowe płatności przez kontrahentów” lub inaczej „przekraczanie terminów płatności przez odbiorców";

b) źródłem problemów są również czynniki wewnętrzne. Pracodawcy dostrzegają problemy wewnątrz firmy i rozwiązują je swoimi metodami - na własnym "podwórku”. To przede wszystkim często powtarzające się rosnące koszty pracy. Powodują, iż: 
„prezes firmy pilotującej projekt wciąż szuka oszczędności - obniżenie kosztów działania firmy";

c) inny ankietowany podejmuje działania zmierzające do optymalizacji:

„zmniejszenia zatrudnienia w stosunku do mocy produkcyjnej tj. liczba pracowników / jeden megawat mocy produkcyjnej, zmniejszenie kosztów produkcji w stosunku do megawata mocy produkcji".

Problemy natury wewnętrznej zdominowały trudności z utrzymaniem środków na własne inwestycje w związku z rozwojem lub utrzymaniem bieżącej działalności. Wymieniana „konieczność kosztownych inwestycji” dotyczy:

„budynków firmy wymagających ciągłych remontów”, „wyeksploatowanych urządzeń, (...) remontów i modernizacji”, „unowocześniania zaplecza sprzętowego", "problemów lokalowych, (...) podniesienia komfortu komputerowego i obsługi", „wymianę starych urządzeń, braku finansów na klimatyzację", "środków na inwestycje związane z rozwojem nowych technologii i ich wdrożeniu” oraz "braku możliwości wykupu na własność lokalu w którym prowadzona jest działalność".

Tylko dwukrotnie zasygnalizowano trudności ze zbytem towarów i poszukiwaniem zleceń na usługi, co ma związek ze

„skomplikowanymi, niejednoznacznymi procedurami współpracy z niektórymi klientami".

Takie problemy dostrzega pracodawca neutralny (w typologii Gilbride'a), którego głównym przedmiotem zainteresowania jest klient.

Jak widać z uzyskanych wyników badań elementy kultury pracy nie ograniczają się do jednego wymiaru jakim jest konkretny styl prowadzenia organizacji. Równoczesna orientacja zarówno na zadania, jak i na pracownika nie tylko jest możliwa, ale realnie realizuje się w badanych organizacjach. Analiza wypowiedzi wskazuje, iż nie ma sprzeczności w tym, aby realizując biznesowe cele kierować się troską o zadowolenie pracowników. Jest to kwestia zakresu dominacji celów biznesowych kosztem zainteresowania ludźmi. W badaniach własnych obserwowane wartości najczęściej dotyczyły biznesowych celów pracodawców. Trudno się temu dziwić, jeśli podstawowym zadaniem organizacji jest wypracowanie zysku. Nie chodzi jednak o to, aby rezygnować z celów biznesowych, ale wypracować model elastycznego pracodawcy o dwuwymiarowej naturze przywództwa. Otwartość pracodawcy realizuje się najczęściej w sposobie komunikowania się z załogą. W większości deklarują bliski, bezpośredni kontakt, przez co tworzy się atmosfera dbałości o potrzeby pracowników. Pracodawca „wsłuchuje się” w opinie zatrudnionych i bezpośrednio reaguje na dostrzeżone problemy. 


\section{Wymagania zawodowe}

Najważniejszym zasobem organizacji są ludzie, którzy oddają jej swoją pracę, talenty, zdolności twórcze i energię. Zacząć więc należy od właściwego doboru, szkolenia i doskonalenia ludzi, którzy przyczynią się do osiągania celów organizacji. Z punktu widzenia prowadzonych badań istotne jest czy proces gospodarowania zasobami ludzkimi przewiduje powstanie przestrzeni dla zatrudnienia osób z niepełnosprawnością. Sposób w jaki menadżerowie, właściciele i dyrektorzy prowadzą rekrutację, dobór, wprowadzenie do pracy, szkolenia i doskonalenia, może ujawnić czy istnieją warunki w procesie gospodarowania zasobami ludzkimi, z których mogłyby skorzystać chętne do pracy osoby z niepełnosprawnością. Gospodarowanie zasobami ludzkimi jest procesem ciągłym, zmierzającym do zatrudnienia odpowiednich ludzi na odpowiednim miejscu. Służy temu właściwie przeprowadzona rekrutacja, w wyniku której tworzy się dostatecznie dużą pulę kandydatów do pracy zgodnie z przewidzianym planem zasobów ludzkich. Kandydatów zazwyczaj poszukuje się za pomocą ogłoszeń w prasie i w czasopismach fachowych, agencji pośrednictwa pracy, przekazywanych ustnie informacji lub podczas spotkań w szkołach i na uczelniach. Z punktu widzenia szans dla osób z niepełnosprawnością im więcej źródeł rekrutacji tym większa szansa na dotarcie do zainteresowanych osób z niepełnosprawnością.

Niektórzy pracodawcy korzystali z co najmniej trzech źródeł rekrutacji. Najczęściej korzystano z Internetu, ogłoszeń w gazetach oraz zgłoszeń z Urzędu Pracy. Pojawiły się też „okoliczne wydziały zatrudnienia”, ,korzystanie z usług agencji specjalizujących się w szukaniu specjalistów na rynku” oraz "firmy rekrutacyjne". Niektórzy pracodawcy współpracowali z instytucjami pracującymi na rzecz osób z niepełnosprawnością: „ppozyskujemy pracowników niepełnosprawnych z warsztatów terapii zajęciowej, Stowarzyszenia Osób Niepełnosprawnych" i „korzystaliśmy z Towarzystwa Integracja". Wśród pozostałych pracodawców pojawiły się inne możliwe źródła rekrutacji: „ogłoszenia na tablicy ogłoszeń", „wywieszki o zatrudnieniu pracownika na zewnątrz firmy", pozyskiwanie pracowników ze szkół przyzakładowych i tzw. rekrutacja „szeptana” Najczęściej wykorzystywanym źródłem pozyskania pracowników wśród wszystkich pracodawców były oferty Urzędu Pracy (Grodzkiego lub Powiatowego), w dalszej kolejności ogłoszenia prasowe, i w końcu ogłoszenia w Internecie. Pojawiające się opinie na temat współpracy z instytucjami ułatwiającymi funkcjonowanie na rynku pracy były zdecydowanie negatywne:

„Firma pilotuje rekrutację we własnym zakresie. Doświadczenia w kontaktach z instytucjami państwowymi są zdecydowanie negatywne, np. PUP jest instytucją dysfunkcjonalną, oferty zamieszczane na tablicach mają się nijak do warunków rynku pracy". 
Inne opinie podejmują problem niskiej efektywności tego źródła rekrutacji:

„powiatowy urząd pracy - ta forma poszukiwania jest mało efektywna. Pomimo wielu osób zarejestrowanych do urzędu o wymaganych kwalifikacjach, osoby niechętnie zgłaszają się do pracodawców”, druga opinia mówi, iż „obsługa tych zgłoszeń z urzędu jest bardzo miła i sprawna, niestety liczba pracowników pozyskiwanych w ten sposób jest znikoma".

Zdecydowana większość nie współpracuje i nie ma doświadczenia we współpracy z instytucjami działającymi na obszarze województwa lub kraju:

„Brak kontaktów z MPiPS. By mieć wpływ na rynku pracy w kontaktach z instytucjami państwowymi przedsiębiorca musi zrzeszać się w różnych stowarzyszeniach".

Nadal wśród pracodawców popularnym sposobem pozyskiwania wartościowego pracownika jest zdanie się na intuicję i zawierzenie znajomościom, które miałyby potwierdzać czyjąś przydatność na stanowisko. Pracodawcy przyznają się do przyjmowania pracowników na podstawie polecenia znajomych.

Istotnym udogodnieniem $\mathrm{w}$ kontaktach z potencjalnym kandydatem na stanowisko pracy są nowoczesne technologie, szczególnie Internet. Pracodawcy dzielą się na tych, którzy korzystają i doceniają ułatwienia, jakie niesie ze sobą korzystanie z jego możliwości oraz na tych, którzy przedkładają tradycyjne sposoby rekrutacji. Zwolennicy pierwszego sposobu rekrutacji akcentują, że korzystanie z Internetu jest łatwe i szybkie - Internet:

„przyspiesza znacznie proces rekrutacji” (..) „łatwiejszy dostęp do potencjalnych kandydatów", , ,jest dużo szybsza możliwość wykonania odpowiedzi na postawione pytania”, "łatwiejsza możliwość komunikacji”.

Internet stanowi doskonały kanał w przekazywaniu wszelkiej dokumentacji:

„ułatwia pracę, nie muszą (podań) składać osobiście”, „ułatwiły informację o konkursach (...) oraz dostępność dokumentacji dołączonej do aplikacji osób zgłaszających się", "pozwala na szybki przepływ dokumentów”.

No i w końcu „nie generuje dużych kosztów”. Przeciwnicy Internetu podkreślają potrzebę osobistego kontaktu z kandydatem:

„Według mnie nowoczesna technologia wpływa na omawiane kontakty w sposób minimalny. Ostatecznie i tak decyduje spotkanie bezpośrednie (sfera psychologiczna funkcjonowania ludzi pozostaje taka sama bez względu na formę)”.

Kolejnym krokiem w procesie gospodarowania zasobami ludzkimi w organizacji jest właściwy dobór kandydata na stanowisko pracy. Standardowa procedura zatrudniania powinna obejmować kilka etapów i nosić cechy systemowego podejścia do kandydata: analizę podania o pracę, wstępną rozmowę kwalifikacyjną, testy, sprawdzanie dotychczasowych doświadczeń i referencji, pogłębioną roz- 
mowę kwalifikacyjną, badania lekarskie i wreszcie ofertę pracy. Pożądanym działaniem pracodawcy z punktu widzenia zatrudniania osób niepełnosprawnością jest korzystanie z różnorodnych sposobów poznania kandydata i użycia różnych rodzajów kontaktu zarówno subiektywnych, jak i obiektywnych. Wywiady i sprawdzanie referencji byłyby podejściami subiektywnymi, podczas gdy testy i przebieg dotychczasowego zatrudnienia są obiektywnymi sposobami poznania kandydata.

Analizowane wypowiedzi pracodawców dają obraz mało profesjonalnego doboru kandydatów na stanowiska pracy. Niektórzy pracodawcy korzystali z więcej niż dwóch sposobów poznania kandydata. Najpełniejszą procedurę zaprezentował pracodawca zatrudniający osoby z niepełnosprawnością:

„Kandydat do pracy przechodzi rozmowę kwalifikacyjną, najpierw z osobą odpowiedzialną za dany dział lub pion, a następnie z dyrektorem danego działu lub pionu. Kandydat na rozmowy musi przynieść wszelkie wymagane dokumenty, tj. zaświadczenia ukończonych kursów oraz orzeczenie o grupie niepełnosprawności (jeśli ją posiada). Po pozytywnym zakwalifikowaniu kandydat jest kierowany do lekarza medycyny pracy, co jest bardzo ważne w przypadku zatrudniania osób niepełnosprawnych".

Pozostali korzystający z różnych sposobów weryfikacji przydatności do miejsca pracy kierowali się:

„bezpośrednią rozmową, historią pracy, poleceniem przez osoby trzecie”, „rozmową kwalifikacyjną na podstawie dokumentów, następnie referencje oraz - jeśli to możliwe - wywiadem i sprawdzeniem tej osoby” oraz „rozmową kwalifikacyjną z kandydatem, poleceniem któregoś pracowników, zatrudnieniem na okres próbny".

Daje się zauważyć brak równowagi i wystarczającej różnorodności w podejściu obiektywnym i subiektywnym. Preferowanym przez pracodawców sposobem doboru kandydata jest obarczona subiektywnością rozmowa kwalifikacyjna (przykładowo przeprowadzona z kandydatem na stanowisko niskiego szczebla może mieć charakter zdawkowy lub może być pozbawiona wiarygodności przez nadmierne wyolbrzymianie przez pracodawcę zalet miejsca pracy, a ze strony kandydata przesadzaniem $w$ przedstawianiu swoich kwalifikacji). Naoczne przekonanie się o umiejętnościach kandydata stanowi w ich opinii gwarancję niepopełnienia pomyłki, ale świadczy też o braku zaufania do prezentowanych przez kandydata dokumentów. Podobnie z referencjami z poprzednich miejsc pracy znalazły się w grupie najchętniej wykorzystywanych sposobów doboru kandydata na stanowisko. Zadowolenie z efektów pracy u poprzedniego pracodawcy jest najlepszą rekomendacją do zatrudnienia pracownika. Jedynie dwaj pracodawcy polegali na funkcjonujących przyzakładowych szkołach zawodowych i na podstawie wyników nauki lub wskazania dyrektora placówki kandydat otrzymywał zatrudnienie. 
Pracodawcy poszukujący pracownika starają się określić, w jakim stopniu kandydat nadaje się na dane stanowisko i jakie ma doświadczenie. Starają się określić, w jakim stopniu kandydat odpowiada ich koncepcji dobrego pracownika i czy jego osobowość, doświadczenie, osobiste wartości i styl działania są zgodne z daną organizacją i jej kulturą. Dobierając pracownika do odpowiedniego miejsca pracy pracodawcy poszukują $\mathrm{w}$ nim cech, które oceniają jako najbardziej przydatne i wartościowe. $\mathrm{W}$ wypowiedziach pracodawców na temat cech poszukiwanych u pracownika pojawiły się takie sformułowania, jak:

„Nie mamy preferencji, jeśli chodzi o cechy osobowości, jedynie ograniczenia wynikające z rodzaju niepełnosprawności”, „,chęć pracy, dyspozycyjność, umiejętność pracy w grupie, podstawowa wiedza o akcesoriach meblowych i/lub łatwość i chęć uczenia się, uczciwość - współodpowiedzialność materialna pracowników”, „komunikatywność, empatia, umiejętność słuchania, planowanie czasu pracy, umiejętność negocjowania, podejmowania decyzji, wykształcenie wyższe, obsługa komputera, umiejętność redagowania pism”, „uczciwość, zaangażowanie, inicjatywa, sumienność, otwartość, chęć podnoszenia swoich kwalifikacji poprzez szkolenia”, „,bezkonfliktowość, chęć rozwoju, rzetelność, uczciwość”.

Pracodawcy podkreślają uniwersalne cechy, jakimi powinni charakteryzować się pracownicy bez szczególnego wskazania tych cech, które byłyby specyficzne dla konkretnego stanowiska pracy. Nie wymagają konkretnych umiejętności typowych dla kompetencji twardych lub podkreślają posiadanie przez pracowników cech o szerokim zakresie, a nie tylko jednego typu. Inni pracodawcy preferują takie cechy, które mogą przełożyć się na efektywność pracy. Stąd pojawiły się sformułowania:

„Sumienność, pracowitość, wykształcenie”, „kwalifikacje, umiejętności, dyspozycyjność”, „„dokładność, rzetelność, chęć pracy, zaangażowanie”, „poszukujemy osób które potrafią działać w zespole, są zdyscyplinowane, sumienne", ,kkompetencje zawodowe - wykształcenie, doświadczenie, odpowiedzialność".

Wśród pracodawców znalazły się wypowiedzi mówiące o pożądanych cechach typowych dla danego stanowiska pracy. Pracodawcy poszukują kandydatów o konkretnych umiejętnościach zawodowych. Odniesienie się do umiejętności interpersonalnych może $\mathrm{w}$ tym wypadku być postrzegane jako umiejętność wymagana na danym stanowisku pracy. Pracodawcy podkreślają kombinacje kompetencji twardych i miękkich, jak chociażby jeden deweloper:

„Odpowiednie kwalifikacje osobowościowe dla wykonywania zawodu nauczyciela, komunikatywność u pracowników biurowych, kwalifikacje zawodowe u konserwatorów (...). Cechy osobowe: komunikatywność, umiejętność działania pod presją, cierpliwość, umiejętność zarządzania czasem, konsekwencja w działaniu, elastyczność, lojalność, pozytywne nastawienie do życia, wymagania zawodowe: zdolność radzenia 
sobie z nowymi sytuacjami, zdolność szybkiego uczenia się, umiejętność prowadzenia negocjacji, umiejętność pracy w zespole, umiejętność wykorzystania nowoczesnych technologii w pracy".

U innych:

„Wymagania: wykształcenie średnie, prawo jazdy, znajomość rynku branżowego, znajomość technologii komputerowych, cechy osobowe: odpowiedzialność, punktualność, odporność na działanie pod presją czasu, komunikatywność, uczciwość (...) Umiejętność pracy w zespole, sprawność manualna, dyspozycyjność”, „kreatywność, odporność na stres, otwartość na zmiany, specjaliści o dużej wiedzy w poszczególnych działach".

Odpowiedzi wszystkich uczestników badania utworzyły katalog najbardziej pożądanych cech kandydata na pracownika. Pracodawcy kierują się nimi podczas rekrutacji i dobierają pracowników zgodnie z preferowanymi atrybutami. Pracodawcy nad kompetencje zawodowe przedkładają kompetencje społeczne. W zakres kompetencji społecznych wchodzą tzw. kompetencje przenośne, które można wykorzystać z powodzeniem w wielu różnych kontekstach sytuacyjnych. Są to kompetencje uniwersalne, przydatne podczas pełnienia różnych ról zawodowych i wypełniania rozmaitych zadań (np. rzetelność, komunikatywność, uczciwość, dokładność, sumienność itd.). Pracodawcy przyznają, że zatrudniając pracownika kierują się głównie jego predyspozycjami do funkcjonowania między ludźmi. Spośród twardych, mierzalnych właściwości pracownika pracodawcy poszukują kandydatów posiadających w pierwszej kolejności odpowiedni zakres wiedzy i kwalifikacji branżowych. Wykształcenie pojawiło się w dalszej kolejności, a umiejętności specjalne, jak znajomość obsługi komputera, znalazły się na końcu listy najbardziej poszukiwanych własności pracownika.

Spośród dwóch cech podanych pracodawcom jako przykładowe do oceny pracowników: pracownik szybko uczący się, pracownik uległy, zdecydowana większość pracodawców uznała uczenie się za istotniejszy warunek powodzenia w realizowaniu zadań, przed jakimi staje pracownik. W uzasadnieniu wyborów przytaczają konieczność dostosowania się do szybko zmieniających się warunków rynkowych, obszerność zadań, jakim musi sprostać pracownik, wprowadzaniem nowości:

„Dynamiczny charakter działalności firmy oparty na elastycznym podejściu do klienta i rosnących wymaganiach rynku wymusza ciągłe doskonalenie umiejętności i poszerzenie zakresu wiedzy".

Pracodawcy przez takie wybory starają się realizować model pracownika odpowiadającego współczesnemu zapotrzebowaniu rynku. Dla niektórych synonimem jest pracownik „ambitny, zdolny, samodzielny”. Stanowiłby on portret nowoczesnego pracownika, człowieka skłonnego do szybkich zmian, reagującego na otoczenie, 
mobilnego, innowacyjnego itd. Oczekiwania są więc duże. Nie ma w nich miejsca na zaufanie, spolegliwość, integrację i egalitaryzm.

Aby pracownik w wartościowy sposób wypełniał powinności pracownicze należy dostarczyć mu potrzebnych informacji. Wówczas bezkonfliktowo i skutecznie może działać w organizacji. Umożliwiają mu to oferowane przez zakład pracy systemy stażów lub dokształcania. Odbywają się one pod okiem starszego, doświadczonego kolegi, jeśli pretendent na stanowisko ukończył wcześniej właściwą szkołę zawodową:

„Prowadzimy system stażów dla absolwentów celem przyuczenia i przygotowania do wykonywania pracy w wybranym zawodzie".

Bywa, że pracodawcy narzekają, iż muszą przyuczać do zawodu we własnym zakresie na skutek braku szkół zawodowych:

„W naszej firmie stosuje się przyuczenie do zawodu - coraz mniej osób, które opuszcza szkoły. Są to wstępne przyuczenia na stanowiska pracy i rozmowie określającej oczekiwania wyników pracy od tej osoby".

Brak szkół powoduje też niemożność prowadzenia stażów dla absolwentów i w ten sposób pozyskiwania nowych pracowników:

„Prowadziliśmy system stażów, kiedy były szkoły - handlowe zawodowe. Kształciliśmy uczniów z praktycznej nauki zawodu".

Pracodawcy traktują okres próbny jako przygotowujący do stawianych wymagań.

Istnienie skutecznego programu włączenia do pracy zwiększyłoby możliwości adaptacyjne osób z niepełnosprawnością do nowego stanowiska pracy. Pozbawiając ich takiej szansy uniemożliwia się im sprawne wchodzenie w środowisko pracownicze. Brak pozytywnych doświadczeń na początku kariery zawodowej często odgrywa krytyczną rolę w zawodowej karierze danego pracownika w organizacji. Bywa przyczyną pojawiającej się fluktuacji, która niemal zawsze jest najwyższa wśród nowo przyjętych pracowników. Pracodawcy w ograniczonym zakresie zapewniają pracownikom naturalne, profesjonalne włączenie do załogi.

\section{Doświadczenie i wsparcie pracodawcy.}

Wsparcie może obejmować takie działania pracodawcy, które związane są odpowiedzią na zmieniającą się indywidualną sytuację pracownika. To wszelkie działania mające na celu wypracowanie sprzyjającej atmosfery w miejscu pracy. 
Poczucie przynależności do organizacji jest wynikiem przemyślanej strategii mającej na celu integrację załogi. Sprzyja identyfikacji z celami organizacji, podnosi motywacje, spaja zespół, wyznacza wspólne zadania. Pomoc dla pracownika może przyjąć postać szkoleń, kursów, treningu, wykładów. Zawsze powinna pojawić się wtedy, gdy pracownik zgłasza taka potrzebę [Gilbride i in. 2003].

Osoba z niepełnosprawnością lub inna wymagająca pomocy powinna skorzystać z możliwości odbycia szkolenia celem wsparcia jej w miejscu pracy. Na podstawie uzyskanych wypowiedzi pracodawców wiadomo, że droga do uzyskania tego wsparcia jest kręta lub uboga $w$ oferty. W większości zajmują się tym przeznaczone do tego komórki organizacyjne, jak: wydziały kadr, wydziały organizacyjne lub działy rozwoju zasobów ludzkich. Kontakt z tym komórkami odbywa się najczęściej za pomocą kierowników, przełożonych i specjalistów zatrudnionych dla celów szkoleniowych. Szkolenia odbywają się na terenie zakładu pracy i prowadzone są przez własnych pracowników:

„Pracownik chcący odbyć przeszkolenie musi zgłosić się bezpośredniemu przełożonemu. Bezpośredni przełożony składa wniosek o skierowanie na szkolenie. Po akceptacji dyrektora przedsiębiorstwa lub dyrektora ds. ekonomiczno-finansowych pracownik może odbyć przeszkolenie. Osoba zajmująca się szkoleniem wyszukuje odpowiedniej oferty".

Do pełnej profesjonalizacji szkoleń przyznaje się zaledwie czterech pracodawców. Wówczas przeprowadzają je specjalistyczne firmy zewnętrzne, które oprócz doskonalenia umiejętności zawodowych, zadbają również o trening kompetencji miękkich:

„Mamy określone rodzaje szkoleń zewnętrznych, obowiązkowych przez dodatkowe szkolenia z różnych form sprzedażowych, motywujących".

Jeden pracodawca oferował specjalne, przeznaczone dla niepełnosprawnych formy doskonalenia:

„Osoby niepełnosprawne mają opracowywane indywidualne programy rehabilitacyjne, gdzie uwzględnia się szkolenie zawodowe, podnoszenie wykształcenia w szkołach wyższych czy też pozazawodowe ze specjalnych środków na ten cel".

Pracodawca ten wyróżnia się różnorodnością oferty przeznaczonej dla osób z niepełnosprawnością pod względem tematyki, zakresu szkolenia, jak i możliwością uzyskania kolejnych stopni wykształcenia.

Wsparcie powinno pojawić się, gdy pracownik ulegnie wypadkowi lub wraca po dłuższej chorobie. Zmienia się jego sytuacja zdrowotna i zdolność do wykonywania dotychczasowych zadań. Wówczas pracodawca stosuje pewne sposoby ponownego wdrożenia pracownika w jego obowiązki. Mogą one mieć charakter 
przemyślanego procesu lub być jedną z form wewnątrzzakładowego systemy szkolenia. Pracodawcy udzielający odpowiedzi najczęściej twierdzą:

„Nie widzę problemu”, ,To jest sprawa normalna”, „Nie jest to żadna szczególna sytuacja".

i w związku z tym:

„Normalnie pracuje dalej”, „Wraca do swoich obowiązków”, „Pracownik wraca na swoje stanowisko i pracuje".

Według nich nie ma konieczności dodatkowego przeszkolenia lub przekwalifikowania na inne stanowisko pracy. Dla pracodawców prezentujących taką postawę ważne były przede wszystkim umiejętności kandydata do pracy i ich przydatność na danym stanowisku. Stan zdrowia nie stanowił żadnego kryterium. Niewykluczone, że pracodawcy w ten sposób pragnęli podtrzymać pozytywny obraz siebie jako wyrozumiałych i tolerancyjnych wobec wypadków losowych. Natomiast organizacje, które oferują wsparcie, proponują je w formie:

- okresu przystosowania do zmienionych warunków pracy:

„Wyznaczam mu okres dostosowawczy i czasowego opiekuna”, „Powoli dochodzi do zakresu swoich obowiązków”, "Staram się aby adaptacja następowała w sposób naturalny dla danej osoby. Spokojnie i powoli wchodziła w swoje obowiązki zawodowe".

- zmiany dotychczasowego stanowiska pracy zgodnie z aktualną sytuacją zdrowotną pracownika:

„Zostaje poinformowany o nowych obowiązkach i do pracy”, „Przeniesienie na inne stanowisko".

- przeszkolenia i zgodnie ze wskazaniami lekarza podjęcie stanowiska pracy:

„Ponowne przeszkolenie i przyuczenie”, „Przeszkalam go i daję mu zadania, z którymi powinien sobie radzić", "Jest obowiązek ponownego przeszkolenia pracownika na jego stanowisku pracy”, „Po uzyskaniu zaświadczenia lekarskiego o zdolności do pracy i przeszkoleniu BHP wraca na własne stanowisko lub adekwatne do jego możliwości zdrowotnych".

Wśród badanych pracodawców uderza brak modelu wsparcia w związku z możliwością wystąpienia niepełnosprawności u pracowników. Nie traktują sytuacji powrotu po dłuższej chorobie lub wypadku jako sytuacji wymagającej specjalnych rozwiązań. Wsparcie według pracodawców nie jest konieczne. Realizując cele ekonomiczne i finansowe skupiają się na obowiązkach pracownika wobec firmy.

Na efekty finansowe firmy wpływ mają zachowania indywidualne i grupowe członków organizacji. Zachowania te kształtują nagrody i zachęty. Dobrze zapro- 
jektowane systemy zachęt są zgodne z celami i strukturą organizacji. Motywują pracowników do kierowania swojej działalności na osiąganie celów organizacji. Każda organizacja, jeśli stawia sobie cele, to powinna również dysponować mechanizmami wzbudzającymi motywację do realizacji tych celów. Mechanizmy te są szczególnie przydatne wobec osób niepewnych, z poczuciem wykluczenia, mało zintegrowanych.

Wypowiadający się pracodawcy nie posiadają systemu motywacji dla pracowników. Należą do nich głównie zakłady pracy określone jako zamknięte. W obecnej sytuacji finansowej zakładów, niektórzy twierdzą, że pensja wypłacana regularnie i bez opóźnień jest wystarczającą motywacją do dobrej pracy:

"Jest to firma z tradycjami, motywacją jest wypłata w terminie i pochwała szefa”, „Dobra atmosfera, stabilizacja finansowa, dobry zespół są dla wszystkich motywacją".

Reszta ankietowanych respondentów może się pochwalić co najmniej skromną ofertą nagród i świadczeń. Wymieniane są premie uznaniowe, finansowe, motywacyjne, kwartalne, uzależnione od wyników pracy. Mówi się też o możliwości awansu, o otrzymaniu samochodu służbowego, oraz możliwości odbycia szkolenia (dziś szkolenia zewnętrzne są kosztowne i finansowanie ich przez zakład może być uznane za formę dodatkowego wynagrodzenia lub wsparcia). Wachlarz przytoczonych $\mathrm{w}$ ankietach propozycji uzupełnia wypowiedź, iż formą finansowego wsparcia są

„Systemy motywujące oparte na badaniu potrzeb pracowników - system kafeteryjny”.

System ten umożliwia dostosowanie nagród do faktycznych potrzeb pracownika i umożliwia samodzielny wybór jednego lub kilku benefitów według indywidualnych preferencji. Ma to szczególne zastosowanie w zróżnicowanym środowisku pracy - uwzględnia wiek, sytuację materialną, rodzinną, cechy osobowości, płeć oraz zainteresowania. Uwzględniałby również potrzeby o charakterze specjalnym, jak choćby te, które zgłaszają osoby z niepełnosprawnością. Ponadto taki system wsparcia umożliwia podmiotowe traktowanie pracownika - sam pracownik ma wpływ na to w jaki sposób zostanie doceniony. Szkoda jedynie, że ten system nie cieszy się dużą popularnością wśród pracodawców.

Zwarta, solidarna grupa jest pożądanym instrumentem dla wielu menadżerów $w$ firmach. Obecnie coraz częściej zamiast realizować cele za pomocą dawnych hierarchii wprowadza się tworzenie grup, zespołów zadaniowych poprzez działania integracyjne. Grupy lub zespoły wypracowują wspólną strategię dochodzenia do celów, normy obowiązujące w grupie są miejscem wsparcia w obszarze efektywności pracy osób o mniejszej wydajności, umożliwiają pełnienie funkcji w zależności od kwalifikacji i umiejętności (a więc są miejscem elastycznego dostosowania zadań do indywidualnych predyspozycji pracownika), wzmacniają 
więzy pomiędzy poszczególnymi członkami (integrują), umożliwiają wyrównane tempo pracy, rozkładają odpowiedzialność za wynik na wszystkich członków, dają możliwość takiego podziału pracy, dzięki któremu wzrasta zadowolenie z pracy.

Szczególnie cenną inicjatywą scalającą zespół są imprezy integracyjne przeznaczone dla pracowników. Nieformalne spotkania, ciekawe imprezy organizowane po pracy przekładają się na ogólną atmosferę w pracy, skracają dystans między pracownikami, pozwalają przeformatować formalne zespoły powołane do realizacji zamierzonych celów w nieformalne, scalone wspólnymi normami i zasadami. Miałoby to przełożenie na lepszą wydajność we współdziałaniu w ramach powierzonych zadań, zaspokajałoby potrzeby społeczne członków zespołu, dawałoby poczucie bezpieczeństwa, niwelowałoby lęki i irracjonalne uprzedzenia wobec osób zagrożonych wykluczeniem z powodu odmienności czy niepełnosprawności.

W przeprowadzonym badaniu pracodawcy byli pytani wprost o to, jakiego typu programy integracyjne zapewniają przedsiębiorstwa oraz czy była przeprowadzona szczególnie efektywna akcja w celu promocji integracji w miejscu pracy.

Oferta imprez integracyjnych w badanych przedsiębiorstwach jest dość ograniczona, jeśli nie uboga. Nie tylko jest ich niewiele, ale również jakość i różnorodność oferowanych imprez jest bardzo skromna. Są to zazwyczaj wyjazdy lub wycieczki - zagraniczne, integracyjne, turystyczno-rekreacyjne, do kina, teatru, na ognisko lub kulig. Bywają wyjazdy połączone ze szkoleniami w specjalnych ośrodkach szkoleniowych, a pracodawcy podkreślają, że są bardzo udane:

„Szkolenia wyjazdowe połączone ze sportami ekstremalnymi zakończone świetną zabawą".

Pracodawcy nie zadają sobie zbyt wiele trudu, aby uatrakcyjnić nieformalne spotkania. Są to często imprezy okolicznościowe podyktowane kalendarzem świąt religijnych. Należą więc do nich tradycyjne spotkania opłatkowe, przedświąteczne, zabawy karnawałowe. Do szczególnych wydarzeń należą wszelkie jubileusze związane z działalnością zakładu. Wówczas odbywają się

„Obchody dnia Energetyka w formie pikniku, spotkania jubilatami (25 lat pracy), spotkania z emerytami".

Przedsiębiorcy czasem proponują więcej niż jedną formę wspólnego spędzania wolnego czasu. Podają takie możliwości, jak:

„Taneczna zabawa karnawałowa, ogniska, mecze piłki nożnej rozgrywane przez zawodników wyłonionych wśród pracowników, uczestniczą wszyscy chętni”, „Szkolenia wyjazdowe do własnego ośrodka szkoleniowo-wypoczynkowego, wyjazdy pracowników w ramach działalności socjalnej do teatrów i wycieczki zagraniczne. Festyn zakładowy dla pracowników z rodzinami. Działalność wielu sekcji w ramach klubu przyzakładowego", 
Czy

„Wyjazdy integracyjne, kursy tańca towarzyskiego - udała się, zintegrowała grupę, usprawniła ruchowo i emocjonalnie".

Ze wszystkich jednorazowych akcji promujących ideę integracji warta przytoczenia jest wypowiedź, w której poruszono kwestię dostępności budynków dla osób z niepełnosprawnością. Zaznacza się w niej idea działania na rzecz szerszego środowiska. Na pytanie, jaka to była akcja, respondent odpowiedział:

„Włączenie się w konkurs Kraków Bez Barier. Promocja mojej instytucji jako obiektu bez barier".

Dość liczną grupę stanowią natomiast pracodawcy, którzy nie widzą potrzeby organizowania jakichkolwiek imprez scalających pracowników. Idea integracji wydaje się im zbędna, a dobra atmosfera w pracy wystarczy by zapewnić poczucie przynależności do grupy. Pojawiły się takie wypowiedzi, jak:

„Posiadamy bardzo dobą atmosferę w miejscu pracy, w którym spędzamy wspólnie bardzo dużo czasu. Nie ma więc potrzeby organizowania takich przedsięwzięć" (...) „Jednym z kryteriów przyjęcia do pracy są u nas predyspozycje pracownika do pracy $\mathrm{w}$ zespole i dopasowania się do atmosfery w naszej firmie, dlatego nie podejmujemy tego typu akcji” (...) „Dotychczas nie zaistniała konieczność przeprowadzenia akcji integracyjnych. Pracownicy są utożsamieni i zintegrowani w zespole i z firmą".

Przyczyną zaniechania jakichkolwiek działań w celu integracji zespołu może być według pracodawców kultura pracy jaka istnieje w organizacji: „Nie potrzebujemy programów integracyjnych, ponieważ cała kultura organizacyjna sprzyja integracji". Był to pracodawca zatrudniający osoby niepełnosprawne w wymiarze przekraczającym sześcioprocentowy wskaźnik poziomu zatrudnienia.

\section{Zakończenie}

Pracodawcy odpowiedzialni są za prowadzenie w zakładach pracy strategii zarządzania, która uwzględnia kulturę równouprawnienia wpisaną w społeczną odpowiedzialność biznesu. Prowadzone badania miały za zadanie odpowiedzieć na pytanie, jak w praktyce realizowane są postulaty egalitaryzmu i integracji, i czy stosowana przez pracodawców strategia zarządzania zasobami ludzkimi uwzględnia specyficzne potrzeby, jakie wynikają z odmiennych cech osób z niepełnosprawnością. Służyła temu specjalnie skonstruowana ankieta diagnozy skłonności pracodawców do zatrudniania osób z niepełnosprawnością stworzona przez Dennisa Gilbride'a wraz ze współpracownikami na podstawie przeprowadzo- 
nych wywiadów własnych. Uwzględniała wszystkie składowe zarządzania organizacją specyficzne ze względu na potrzeby osób z niepełnosprawnością w miejscu pracy. Analiza jakościowa uzyskanych w badaniach własnych odpowiedzi upoważnia do sformułowania następujących wniosków:

1. Wśród badanych pracodawców nie zidentyfikowano pracodawców, którzy prowadziliby w swoim zakładzie pracy świadomą strategię zarządzania niepełnosprawnością. Nie zaistniał przypadek organizacji, w której zaobserwowano by długotrwały i spójny proces sprzyjający zatrudnianiu osób z niepełnosprawnością.

2. Pracodawcy cenią fachowość, profesjonalizm i wykształcenie pracowników. Wówczas są skłonni tworzyć trwały i stabilny zespół. Kultura równouprawnienia wymaga, aby przydzielona praca była zgodna z wykształceniem i możliwościami. Wobec niewystarczającego wykształcenia osób z niepełnosprawnością możliwości tej grupy społecznej wydają się być ograniczone. Problem w tym, że najczęściej zatrudnieni byli poniżej kwalifikacji, co dowodzi stosowania praktyk dyskryminacyjnych przez pracodawców. Wyjaśnieniem zaistniałej sytuacji mogą być utrwalone postawy pracodawców, w myśl których osoby z niepełnosprawnością pomimo wykształcenia nadal postrzegane są jako mało fachowa siła robocza. Rozwiązaniem mógłby być wprowadzony na terenie zakładu pracy system stażów przeznaczonych dla osób z niepełnosprawnością. Możliwość wykazania się kompetencjami zawodowymi na stanowisku pracy przekonałaby niejednego pracodawcę do zatrudnienia takiej osoby.

3. Osoby z niepełnosprawnością zgodnie z kulturą równouprawnienia powinny mieć zapewnione jednakowe szanse z pełnosprawnymi pracownikami w zdobywaniu doświadczenia i umiejętności niezbędnych do rozwijania dalszej kariery zawodowej. Badania własne w obszarze proponowanych systemów wsparcia i podnoszenia kwalifikacji w zakładach pracy dają obraz pracodawcy, który niewystarczająco dba o formy doskonalenia pracowników. W systemie włączenia pracownika do nowych obowiązków pracowniczych niektórzy pracodawcy przewidują system stażów i możliwość odbycia tzw. okresu próbnego. Jednak badani pracodawcy nie widzieli takiej potrzeby, a odpowiedzialność za przygotowanie pracownika przerzucali na system kształcenia zawodowego, który zresztą $\mathrm{w}$ ich opinii jest niewydolny. Pracodawcy oraz kierownictwo swoje zaangażowanie $\mathrm{w}$ strategię zarządzania niepełnosprawnością powinno okazywać poprzez utrzymanie $\mathrm{w}$ zatrudnieniu pracowników, którzy stali się niepełnosprawnymi w trakcie trwania stosunku pracy. Miałby temu służyć specjalny program modyfikujący zakres obowiązków do zmienionych potrzeb osoby, która stała się niepełnosprawna. Badane organizacje ograniczają się jedynie do zdawkowego przeszkolenia, a powrót pracownika 
na dotychczasowe stanowisko pracy jest praktyką często stosowaną w zakładach pracy.

4. Rozwój telekomunikacji i technologii informacyjnych znacząco wpływa na sposób i jakość komunikacji z osobami niepełnosprawnymi. Wśród pracodawców technologie te docenione zostały głównie ze względu na szybkość przekazywanych informacji, możliwość przesyłania dokumentów i minimalne koszty, jakie pochłania korzystanie z Internetu. Nowe technologie są też doskonałym kanałem służącym rekrutacji. Stwarzają ogromną szansę poprawy wskaźnika zatrudnienia osób z niepełnosprawnością i mogą stanowić sposób na pokonanie wielu fizycznych i psychologicznych barier. Niestety jak wynika z analizy wypowiedzi pracodawców większość w procesie rekrutacji korzysta z tradycyjnych form, a w szczególności z „rekrutacji szeptanej”, czyli polecenia zaufanych znajomych. Wśród innych subiektywnych podejść do kandydata dominuje rozmowa kwalifikacyjna, która staje się czynnikiem przesądzającym o zatrudnieniu. W sposobie rekrutacji zauważa się również brak współpracy z instytucjami odpowiedzialnymi za aktywizację zawodową osób niepełnosprawnych. Pracodawcy sygnalizują nieprzystawanie ofert z urzędów pracy do warunków rynkowych, a zgłaszający się chętni do zatrudnienia nie spełniają wymaganych oczekiwań.

5. Dla badanych pracodawców wartość danej osoby na rynku pracy wyraża się w jej zasobach kompetencji. Spośród wszystkich kompetencji prezentowanych w opracowaniu wyników badań najbardziej pożądane były te, które związane są ze skutecznym funkcjonowaniem społecznym. Warunkiem sprawnego funkcjonowania pracownika w organizacji byłaby w opinii badanych pracodawców przede wszystkim umiejętność pracy w grupie i predyspozycje do sprawnego komunikowania się z innymi. Taka postawa odpowiadałaby koncepcji pracodawcy otwartego na zatrudnianie osób z niepełnosprawnością, bowiem skuteczni pracodawcy tworzą możliwość powstania złożonej siatki relacji między pracownikami oraz możliwość interakcji społecznych.

6. Ważnym warunkiem kultury równouprawnienia, stosowanej przez pracodawcę otwartego na zatrudnianie osób z niepełnosprawnością, jest aktywność ukierunkowana na integrację załogi. Służyłaby temu działalność rekreacyjno-kulturalna. Ma ona niebagatelny wpływ na pozyskanie i umocnienie relacji koleżeńskich, a jednocześnie zwiększa możliwości samorealizacji i przeciwdziała alienacji. Sprzyja więc rehabilitacji społecznej i zawodowej osób z niepełnosprawnością. Szkoda, że formy te nie są zbyt popularne wśród badanych organizacji. Respondenci jeszcze nie dostrzegają korzyści wynikających z posiadania zintegrowanego zespołu pracowników. Proponowane przez nich formy miały charakter tradycyjnych imprez wynikających z kalendarza świąt, a w formie ograniczały się do tradycyjnych spotkań. 


\section{Bibliografia}

Bartkowiak G., Krugiełka A. (2012), Społeczna odpowiedzialność biznesu w obszarze zatrudnienia: uwarunkowania i korzyści dla pracownika i organizacji, Wydawnictwo „KMB-DRUK”, Parkowo.

Czapliński P. (2010), Raport o stanie zatrudnienia osób niepetnosprawnych w Polsce, Polska Organizacja Pracodawców Osób Niepełnosprawnych, Warszawa.

Domagała-Kręcioch A., Zawisza E. (2002), Postawy studentów uczelni pedagogicznej wobec niepetnosprawności [w:] Wielowymiarowość integracji w teorii i praktyce edukacyjnej, M. Chodkowska (red.), Wydawnictwo Uniwersytetu Marii Curie-Skłodowskiej, Lublin.

Garbat M. (2007), Identyfikacja barier zatrudniania osób niepetnosprawnych w badaniach empirycznych, „Aktywizacja Zawodowa Osób Niepełnosprawnych KIGR”, listopad 4(12).

Gilbride D., Stensrud R., Vandergoot D., Golden K. (2003), Identification of the Characteristics of Work Environments and Employers Open to Hiring and Accommodating People with Disabilities, „Rehabilitation Counseling Bulletin”, vol. 46, no. 3, s.130-137.

Gilbride D., Stensrud R., Vandergoot D., Golden K., Ankieta Otwartości Pracodawcy Employer Opennes Survey (EOS).

ISP ZUS (2009), Pracodawcy o zatrudnianiu osób niepetnosprawnych. Jak jest? Co można zmienić?, Instytut Spraw Publicznych i Zakład Ubezpieczeń Społecznych, Warszawa.

Kostera M. (2003), Antropologia organizacji. Metodologia badań terenowych, Wydawnictwo Naukowe PWN, Warszawa.

Miedzianowska M. (2013), Sytuacja pracowników niepetnosprawnych [w:] Pracownicy o pracodawcach. Społeczna odpowiedzialność biznesu w świetle badań jakościowych, K. Klincewicz (red.), Wydawnictwo Naukowe Wydziału Zarządzania Uniwersytetu Warszawskiego, Warszawa.

Ochonczenko H. (2002), Społeczna integracja osób niepetnosprawnych w opinii liderów środowiska lokalnego ziemi lubuskiej [w:] Wielowymiarowość integracji w teorii i praktyce edukacyjnej, M. Chodkowska (red.), Wydawnictwo Uniwersytetu Marii Curie-Skłodowskiej, Lublin.

Ostrowska A., Sikorska J. (1996), Syndrom niepetnosprawności w Polsce. Bariery integracji, Wydawnictwo IFiS PAN, Warszawa.

Ostrowska A. (1997), Postawy społeczeństwa polskiego w stosunku do osób niepetnosprawnych [w:] Upośledzenie w społecznym zwierciadle, A. Gustvsson, E. Zakrzewska-Manterys (red.), Wydawnictwo "Żak", Warszawa.

Ostrowska A. (2002), Społeczeństwo polskie wobec osób niepetnosprawnych. Przemiany postaw i dyskursu [w:] Społeczne problemy osób niepetnosprawnych, J. Sikorska (red.), Wydawnictwo IFiS PAN, Warszawa.

Woźniak Z. (2007), Główne bariery aktywności zawodowej osób z ograniczoną niepetnosprawnością [w:] Osoby z ograniczona sprawnościa na rynku pracy, A. Brzezińska, Z. Woźniak, K. Maj (red.), Academica Wydawnictwo SWPS, Warszawa. 